\title{
STRINDBERGS VREDE STEMME
}

STRINDBERG'S ANGRY VOICE | The article argues that the affect or emotion of a literary text could be regarded as a dimension of its voice and tone. "Voice" is found on the level of the narrator, "tone" on the level of the implied author. In cinematic metaphors the article proposes "voice" to be analogous with the voice-over in film, and "tone" to be analogous with the background music. The article develops its concept of textual voice from Horace Engdahl, and its concepts of affect, emotion and tone from Sianne Ngai. The literary text to be analysed is August Strindberg's Le Plaidoyer d'un fou that is known as one of the texts in which he voices his monomaniac misogynist anger. The article tries to describe the quality of this angry voice through analysing structures of narration, genre, address, and style, discovering

feverish volatility and paranoia to be its characteristics. The feverish volatility is shown to be linked to the shifting images of Woman that the text exposes. The paranoia is understood through Sianne Ngai's definition of paranoia as an "ugly feeling", and jealous paranoia as connoting femininity. Thus the voice and tone of Strindberg's text are discovered to be much more complex than simple misogynist aggression.

KEYWORDS I voice, tone, anger, August Strindberg, Sianne Ngai.

Denne artikel ønsker at undersøge affekten som en dimension ved tekstens stemme. I den menneskelige tale kommer affekten oplagt til udtryk i stemmen. Og når vi skal beskrive litterære stemmer, gør vi det ofte med følelsesadjektiver: en melankolsk stemme, en munter stemme, en bitter stemme osv. Min litterære smag har haft en særlig forkærlighed for vrede stemmer. De stemmer, hvor vreden giver sproget en særlig energi og fremdrift og gør det særligt velartikuleret. Med August Strindberg som pragteksempel. Det er også ham, der skal være eksemplet her i artiklen, nærmere bestemt hans roman En dåres forsvarstale, der er kendt som en af de tekster, hvor han giver sit monomane kvindehad ren og rasende stemme. Det kan man selvfølgelig vælge at blive feministisk forarget over, eller man kan, som Strindberg-forskningen vægtigt og kvalificeret har gjort det (eksempelvis Fahlgren 1994, Stenport 2004), forstå kvindehadet som en del af den kønsdiskurs, der prægede Strindbergs tid. Det har imidlertid altid forekommet mig, at der i Strindbergs vrede mod kvindekønnet findes noget forløsende, en både etisk og æstetisk kraft, som man går ram forbi, hvis man udelukkende møder værket med feministisk forargelse eller historiserende analyse. Jeg vil her undersøge, om det er muligt gennem stilistisk tekstanalyse nærmere at bestemme denne vrede, denne kraft som en særlig kvalitet ved Strindbergs litterære stemme. Det kræver indledningsvis nogle 
begrebslige overvejelser over "vrede" som en affektiv kategori og "stemme" som en dimension ved den litterære tekst.

\section{Vrede}

Når jeg taler om "vrede" stemmer, taler jeg ifølge nyere affektteori strengt taget ikke om affekt, men om følelse. Til forskel fra den diffuse affekt er en følelse benævnt, sprogligt katalogiseret. Dér hvor affekten er svær at lokalisere til et subjekt, og snarere nærmest meteorologisk er til stede i et miljø, hvorfra den afficerer subjekterne, er følelsen noget, vi forankrer i et subjekts indre (Ngai 25). Dette skel kommer jeg ikke til at respektere stringent i artiklens sprogbrug, da jeg har brug for at kunne tale om stemmen hos Strindberg som en stemme i affekt, også når man godt kan kvalificere denne affekt som "vrede". Til gengæld mener jeg, at denne vrede i høj grad er en del af et affektivt "klima", som kendetegner det fallocentriske kønssystem, og at den cirkulerer mellem subjekterne i en dynamik af projektion og introjektion frem for at kunne lokaliseres til en forestilling om et indre dyb i det enkelte subjekt. Som Ngai skriver, er det interessante måske netop dér, hvor det er svært at lokalisere, om følelserne er subjektive eller objektive, personligt forankrede eller diffust cirkulerende (Ngai 28).

Vreden hos Strindberg er helt overordnet mandens vrede mod kvinden. Hvordan kan denne vrede indfanges og beskrives? "Vrede" er en følelse, der må kvalificeres nærmere: den kan være fuldtonet, bitter, udadrettet, indadvendt, henvendt osv. Den kan være tyrannens, den kan være offerets. Den kan være offerets retmæssige klage, eller den kan være pseudoofferets selvtilfredsstillende brok. Den kan være blandet op med kærlighed, med jalousi, med foragt osv. Den kan gøre en forskel ved at rette sig mod urimelige og undertrykkende forhold, eller den kan være udtryk for selve undertrykkelsens vold, den kan være en ren teatralsk gestus. Den kan sætte grænser, eller den kan opløse dem i raseriets symbiose. ${ }^{\mathrm{I}}$

Det er min tese, at for at kunne kvalificere vreden hos Strindberg nærmere må vi kvalificere tekstens stemme nærmere. Men hvordan gør man det, hvordan analyserer man skriftens stemme, der som udgangspunkt er tavs og kun lader sig høre i læserens hoved?

\section{Stemme og tone}

Inden for litteraturkritikken er det udbredt at karakterisere et værk med ordet "stemme": "en ny stor stemme i dansk litteratur", "forfatteren har fundet sin egen stemme" etc. Inden for litteraturteorien har begrebet været mere over- og ugleset. En undtagelse i skandinavisk sammenhæng er Horace Engdahl, der med Beröringens $A B C$ (1994) udnævnte stemmen til at være konstituerende for det

I For et forsøg på en vredes-typologi baseret på Peter Sloterdijk, Slavoj Zizek og Søren Kierkegaard, se Rösing 2008. 
litterære værk. Engdahl angiver ingen egentlig metode for sin karakteristik af litterære stemmer. Når han fastslår, at stemmen er "utilgængelig for maskinlæren”, sigter han formentlig til den formalistiske litteraturanalyse. Selv går han mere impressionistisk til værks, bl.a. ved at karakterisere sine litterære stemmer med metaforer. Stemmen i Dostojevskijs Kaldermennesket sammenlignes eksempelvis med "en svejseflamme", som "brænder igennem beretningens halvsandheder" og med "den dumpe klang fra et instrument, som mangler rene toner" (Engdahl II). Til forskel fra Engdahl vil jeg i det følgende læne mig op ad den formalistiske "maskinlære" og forsøge at indkredse stemmen hos Strindberg gennem analyse af udsigelse, retorik og stilistik.

Et greb, Engdahl selv bruger, uden at tematisere det, når han karakteriserer litterære stemmer, er at beskrive, hvem teksten henvender sig til (hvad enten der er en eksplicit adressat, eller man må operere med en implicit læser). Han karakteriserer eksempelvis stemmen i den romantiske digter Wilhelm Müllers Winterreise (senere sat i musik af Schubert) ved at beskrive, hvem den gør læseren til: den ensomme vandrers skygge. Og han karakteriserer Stendhals stemme ved at sige, at den er henvendt til "the happy few", en elitær og indforstået kreds. En stemme formes ikke mindst af, hvordan og til hvem den henvender sig.

Skiftende med begrebet "stemme" bruger Engdahl begrebet "tone", som han faktisk åbner bogen med: "Ingen tekst er begyndt, før forfatteren har slået en tone an” (Engdahl 7). Engdahl stipulerer intet begrebsligt skel mellem stemme og tone, men jeg foreslår, at man lokaliserer stemmen til fortællerens niveau, hvad enten fortælleren er eksplicit eller implicit, mens tonen må lokaliseres til den implicitte autors niveau. Med metaforer fra filmens verden kan man tænke sig stemmen som voice-over, mens tonen snarere ville befinde sig på underlægningsmusikkens niveau. Man får fat i stemmens, og fortællerens, niveau, hvis man spørger: Hvordan skal teksten læses op? Man får fat i tonens, og den implicitte autors niveau, hvis man spørger: Hvilken type underlægningsmusik ville egne sig til teksten?²

Sianne Ngai kobler i sin bog Ugly Feelings tekstens affektive dimension netop til dens "tone". Tone definerer hun som "en litterær teksts affektive pejling, orientering eller 'kurs' i retning af sit publikum og verden". Hun understreger, at tonen er et formelt aspekt ved værket: "... det formelle aspekt ved et værk, som har gjort det muligt for vidt forskellige kritikere at beskrive et værk eller en gruppe af værker som 'paranoidt', 'euforisk' eller 'melankolsk'” (Ngai 43). I Ngais definition gælder det for tonen som for affekten, at den hverken kan reduceres til læserens emotionelle respons (jeg græder, altså er tonen sørgelig) eller tekstens repræsenterede/benævnte følelser (den handler om en vred mand, altså er tonen vred) (Ngai 4I).

At tonen ikke kan reduceres til de i teksten repræsenterede/benævnte følelser eller læserens følelsesmæssige respons, betyder ikke, at disse er irrelevante for analysen af tonen. Når Ngai analyserer tonen i Herman Melvilles The Confidence Man, kredser hun i høj grad om følelsen "confidence", tillid, som jo allerede er benævnt

2 For en nærmere diskussion af litteraturteoretiske begreber om "stemme", se Rösing 2012. 
med titlen. Lige såvel bliver læserens ubehagelige, diffuse følelse af støj på linjen og mangel på klar følelsesmæssig identifikation central for hendes udredning af romanens kapitalisme-symptomatiske affektive tone som en diffus følelse uden forankring i et subjekt. (Ngai 7I)

Selv om "tone" principielt heller ikke er det samme som tonen i fortællerens eller karakterernes stemmer, bliver den slangeagtige hvislen, som Ngai finder i fortællerstemmen (Ngai 6o), og de støjende onomatopoietika, hun finder i karakterernes tale (Ngai 64), vigtige for hendes bestemmelse af den overordnede tone.

I min analyse af En dires forsvarstale kommer jeg til at bruge "stemme" og "tone" i flæng. Men begrebsligt må man skelne, og afslutningsvis vil jeg forsøge at sammenfatte mine iagttagelser og indfange den overordnede "tone" i en overvejelse over, hvilken slags underlægningsmusik man kunne tænke sig til Strindbergs jegfortællers konstant kværnende, verbuose stemme.

Lad os nu se, om vi formår at indkredse stemmen i En dåres forsvarstale. Og om det kan hjælpe os til at indkredse vreden. Min analyse retter sig mod Hans Levanders svenske oversættelse fra 1976. Jeg citerer på dansk i min egen oversættelse, der forsøger at holde sig så tæt på det svenske som muligt. Strindberg skrev oprindeligt bogen på fransk (I887) og ønskede ikke, at den skulle udgives på noget skandinavisk sprog. Første gang den blev udgivet, var det på tysk i I893 (det skaffede Strindberg en retssag på halsen), og da den i I895 kom på fransk, var det i en stærkt bearbejdet udgave. Den svenske oversættelse fra 1976 bygger på det franske originalmanuskript, som efter mange års forsvinden dukkede op i Oslo i I973. Man kunne mene, at analyseobjektet burde være den franske original, når man nærlæser efter sådan noget som stemme. At det gælder om at komme forfatterens originale stemme så tæt som muligt. Her har jeg imidlertid valgt snarere at karakterisere stemmen, sådan som den har gjort sin indflydelse gældende siden I976 og stadig gør det, som en svensk stemme, en del af den nordiske frem for franske litteraturhistorie.

\section{Den vrede dåre}

I En dåres forsvarstale fremlægger en jegfortæller sin ægteskabshistorie, fra tiden op til den store forelskelse og frem til skilsmissen. Jegfortælleren Axel er en litterær omstøbning af Strindberg selv, og hans (eks)hustru, som i romanen er forsynet med madonna-navnet Maria, er en litterær version af Strindbergs første hustru, den finlandssvenske, fattigaristokratiske skuespillerinde Siri von Essen.

Jegfortællerens stemme er vred, bitter, hadefuld, paranoid, når den fremturer i sit had til ekshustruen og kvindekønnet. Samtidig er der en voldsom formgivende kraft i denne stemme. Det er ikke vrede af den slags, der truer med at opløse sproget og blive til urbrøl. Jo mere urimelig og hyperbolsk jegfortælleren er, jo mere velartikuleret bliver han, til gispende, fnisende fryd, bevægelse eller forargelse for sin læser. Som når han karakteriserer sin hustrus første mand som "en tom vokstavle hvor den svageste kvindehånd formåede at indriste sine dumheder og indfald 
udsprungne af et embryonalt intellekt" (Strindberg 63). Som når han beskriver sin hustru med svulstens metafor: "Denne udvækst på min sjæl som har taget skikkelse af en kvinde" (Strindberg 85 ). Eller som når vreden får sit crescendo af akkumulerende opremsninger: "Hun tager imod, udsuger min hjerne, forbrænder mit hjerte. Hun har gjort mig til sin skraldespand, hvori hun kaster alt sit affald, sine sorger, sine fejlberegninger, sine bekymringer. Og midt i dette fuldkomne helvede lever jeg mit liv, fremslæber min elendighed, slider for en knap eksistens.” (Strindberg I59)

I det følgende skal jeg forsøge at indkredse stemme og tone i romanen ved at rette opmærksomheden mod genre, udsigelse og henvendelse så vel som repræsenterede følelser - og ved at gribe til musikalske metaforer. Fokus vil være romanens "Indledning", der som en ouverture synes at anslå dens gennemgående stemninger, temaer og tonearter. (I den franske originaltekst hedder den faktisk "Ouverture”.)

\section{Genre og udsigelse}

Til særlige genrer knytter sig særlige litterære stemmer. Med titlens "forsvarstale" angiver Strindbergs roman selv at være en apologi. Og den har langt hen ad vejen apologiens genretræk og tone: den er henvendt, den er argumenterende, men den er også vældig afficeret. Der er tale om den type forsvarstale, som også er et anklageskrift: Jeget forsvarer sig selv ved at anklage sin hustru.

Romanens forord fra I887 har derimod i sit anslag snarere karakter af en bekendelse: "Dette er en forfærdelig bog, det indrømmer jeg uden indvendinger og med svidende anger." Der indrømmes, der angres, men angerens genstand er ikke ægteskabet, men bogen; det er ikke den angrende ægtemand, der taler, det er den angrende forfatter. Og han sætter sig på forhånd i den anklagedes position; hans første sætning er formet som et svar på en anklage. Men straks derefter er han i færd med at retfærdiggøre sig:

"Hvad var det som gav ophav til den [bogen]? Det retmæssige behov for at vaske mit lig inden det bliver proppet ned i kisten.” (Strindberg I7)

Med dette absurde og hyperbolske billede af den anklagede, der vasker sit eget lig, inden det bliver stoppet ned i kisten, anslås den patetiske, aggressive overdrivelses tragikomik, som er en genkommende tone hos Strindberg. Forordets slutning bidrager til denne tone gennem en henvendelse til ekshustruens afdøde mor, som i sin tid har foreslået forfatteren at gøre ægteskabet til emne for en roman: "Lykkelige moder, som fik lov til at gå bort i rette tid, her har du fået dit ønske opfyldt! Romanen er skrevet. Nu kan jeg selv dø.” (Strindberg I7) Her er der ikke sparet på retorisk patos: Den døde mor apostroferes med epitet og udråbstegn, og de afsluttende korte konstateringer imiterer den store retors eller heros fyndighed.

Men dø-det gjorde forfatteren ikke, det bliver læseren fra starten forvisset om i den tekstgestalt, som romanen har haft siden I894, hvor Strindberg tilføjede et nyt 
forord. I dette forord omtaler forfatteren romanens fortæller i tredje person: "Jeg mødte forleden helten i denne roman, og jeg bebrejdede ham, at han havde forledt mig til at offentliggøre sit ægteskabs historie." (Strindberg 15 ) Herefter citeres, hvad romanens "helt" har svaret på "forfatterens" anklager, således at situationens anklage/forsvar (som er implicit i forordet fra 1887) iscenesættes som en eksplicit replikveksling.

Efter at den "anklagede" romanhelt i det nye forord har aflagt endnu en lille forsvarstale, forsvinder forfatterens "anger": "Og jeg angrer ikke længere at jeg har fortalt historien om denne idealisttype." Igen bliver den mulige (men afviste) angers genstand ikke ægteskabet, men ægteskabsromanen.

Med duplikationen af forord, som er læserens indgangsport til romanen, iscenesættes en udsigelsessituation, hvor jeget synes at duplicere sig selv, ikke i en ironisk refleksion (som i en kierkegaardsk kinesisk æske af udgivere, forfattere og fortællere), men i en bestandig omveksling mellem anklage og forsvar, bekendelse og apologi, anger og retfærdiggørelse. En udsigelse, der dels er med til at gøre omskifteligheden til en grundtone i romanen, dels giver den en snert af paranoia. Duplikationen kommer desuden til at forskyde angerens eller apologiens genstand fra ægteskabet til romanen.

Romanens indledende øvelser er ikke slut med de to forord; herefter følger en I3 siders "Indledning", der som sagt har karakter af en ouverture. Også i denne "Indledning" kan forskellige genrer siges at flettes ind i hinanden: til bekendelsen og forsvarstalen føjer sig den videnskabelige undersøgelse. Man kan også sige: Tre forskellige typer "undersøgelse" blandes: den selvransagende, den juridiske og den videnskabelige, med tre dertil knyttede forskellige tonelejer, som væver sig ind og ud af hinanden.

Jeget fortæller retrospektivt, om dengang han, stævnet og bandlyst og "smidt i affaldsbunken", boede med sin familie i en bajersk landsby og fik pludselig, høj feber. Sygdomsforløbet kaster ham mellem varmt og koldt, og mellem kærlighed og mistillid til sin hustru, der fremstilles snart som "lilla mamma", snart som giftmorderske, snart som talentløs skuespillerinde, snart som Dalia med hårsaksen, snart som erotisk-æstetisk åbenbaring, snart som billedskøn Madonna, snart som hunpanter.

Teksten er præget af dialog: ægtefællernes citerede replikveksling og jegets dialog med sig selv samt hans sporadisk markerede henvendelse til "jer" og slutteligt til "læseren". Hermed ikke være sagt, at teksten er "dialogisk" i en demokratisk eller bakhtinsk forstand. Stemmen er tværtimod monoman, for så vidt som den farver alt med sine febrile udsving. Og tekstens komposition er snarere dialektisk end dialogisk, hvis man ved dialektik forstår en bestandig pendlen mellem modsætninger.

Feberen kaster jeget ud i dødslængsel: ’Jeg vil dø! [...] Jeg væmmes ved livet. [...] Måtte mørket udbrede sig og tæppet gå ned!” Men så melder det bajerske landskab sig som et skønt tableau indrammet af vinduets triptykon, og en koncert af fuglekvidder, børnelatter og hustrustemme trænger ind i sygeværelset. Opløftet 
af disse sansninger opildnes jegfortælleren til bekendelse. I bekendelsens modus, henvendt til hustruen, lyder historien om forholdet således:

"Jeg er en grænseløs egoist; jeg har smadret din teaterkarriere for selv at gøre litterær succes; jeg er villig til at bekende alt; tilgiv mig.” (Strindberg 22)

Bekendelsen afløses imidlertid hurtigt af "undersøgelsen", som fremføres i selvciteret indre dialog. Efter en god nats søvn samler tankerne sig med en militaristisk metafor i fortællerens hoved som "regulære tropper", klar til at "holde stand mod disse anfald af sygelige samvittighedskvaler": "Lad os nærmere undersøge, sagde jeg til mig selv, i hvilken henseende jeg har fejlet" (Strindberg 24).

Der er her tale om et retrospektivt citat af egne tanker, og som Dorrit Cohn har gjort opmærksom på, har selve denne udsigelsesform noget utroværdigt over sig (Cohn I62) og antyder en situation af selvoverbevisning eller selvsuggestion frem for selvrefleksion.

Det, der præsenteres som en "undersøgelse", bliver altså snarere en selvsuggestion, og i denne version bliver historien om ægteskabet historien om en "teatergal" kvinde, hvis mand for hendes skyld ofrer sine litterære idéer og skriver et stykke med det ene sigte at skabe en succesrig hovedrolle til hende. Gennem "undersøgelsen” lykkes det også det retrospektive jeg, gennem en lang og kompliceret udredning af ægteparrets økonomi, at overbevise sig selv om, at det er hende, der står i gæld til ham, og ikke omvendt.

Både udsigelses- og genremæssigt er det den bratte omskiftelighed, emblematisk repræsenteret af feberens temperatursving, der karakteriserer romanens toneleje. Den pendler mellem angrende bekendelse og apologetisk anklageskrift, mellem en selvransagende, en juridisk og en pseudovidenskabelig diskurs. Det apologetiske og selvsuggererende giver endvidere stemmen en paranoid klang. I det følgende skal først den febrile omskiftelighed og siden paranoiaen forfølges både i romanens udsigelse og tematik.

\section{Febril omskiftelighed}

Opsat på "at få det hele at vide" stiger den syge i indledningen op af sengen for at tale med hustruen, men afvæbnes straks af det "henrivende maleri”, som hun udgør i den uredte seng med sine tre små børn omkring sig. Der zoomes ind på "den spæde fod", "hvis rosenfarvede tæer kronedes af ulastelige, gennemsigtige negle, et fuldkomment mesterværk, støbt i menneskeligt kød over en antik marmorskulptur.” (Strindberg 29)

Det er bemærkelsesværdigt, at det her igen er et æstetisk tableau, der forårsager et affektivt skift i jeget. Først vinduets tableau af det bajerske landskab, der river ham ud af dødslængslen, så dette "henrivende maleri”, der river ham ud af vreden.

De heftige omslag mellem modsatte følelser følges med feberens omslag mellem varmt og koldt, som kulminerer i scenen, hvor hustruen sidder ved den syges side 
med sin hånd i hans: "jeg følte mig smelte som is, opløst af strålerne fra hendes store øjne, som genspejlede en grænseløs ømhed; og under hendes kys, der blev trykket som et koldt segl på min brændende pande, mærkede jeg, hvordan jeg sank til bunds i ubeskrivelige saligheders dyb.” (Strindberg 23) Bemærk, hvordan kulde og varme her knyttes kiastisk til de to parter: Først smelter hustruen den iskolde ægtemand med sine varme øjne, så svaler hun hans brændende pande med sit kolde kys. Det "kolde segl”, som kysset sammenlignes med, lyder egentlig ikke særlig behageligt og giver associationer i retning af en kold pagt, måske kærligheden forseglet med ægteskabets kolde pagt.

Den heftige omskiftelighed, som får et fysisk billede i feberen, bliver den dominerende tone, der slås an med indledningen. Ouverturen gennemspiller alle de affektive tonearter, som skal udfoldes i resten af romanen: ømhed, forurettethed, beundring, fortvivlelse, resignation, vrede, paranoia, foragt, idoldyrkelse, alle knyttede til hvert sit billede af kvinden. Men det er en ouverture, hvor det ene tema knap når at blive slået an før det afløses af sit kontrapunkt. Og således fortsætter det gennem romanen. Forsøget på at forstå tekstens omskifteligheder som udtryk for en umarkeret vekslen mellem jegfortællerens og jeg-protagonistens perspektiv, som man finder hos Göran Rossholm (Rossholm 206), er for mig at se et forceret forsøg på at distribuere modsætningernes poler frem for at erkende deres sameksistens $i$ både den fortællende og den fortalte bevidsthed; en erkendelse, Rossholm dog også skriver sig frem til, når han understreger, at grænsen mellem de to perspektiver er flydende (Rossholm 2I8).

I sit forord til pocket-udgaven af En dåres forsvarstale skriver den finske forfatter Märta Tikkanen, at det, der gør romanen til stor litteratur, er "de utallige sprækker, hvor Strindberg ikke kan holde den tone, han har sat sig for", dér hvor "forelskelsen slår ned" trods den erklærede hensigt om "at skildre den første hustru som koket, overfladisk, egoistisk, grusom." "Han klarer ikke at give et usympatisk billede af den han engang har elsket inderligt."(Strindberg Io) Tikkanen bruger altså netop ordet "tone" til at betegne fortællerens affektive leje og registrerer, hvordan bogens skiftende toner er knyttet til de skiftende billeder af hustruen.

På de repræsenterede følelsers niveau er og bliver det også den heftige omskiftelighed, der karakteriserer vor helts affektive profil. Et symptomatisk eksempel er episoden, hvor det unge jeg har taget afsked med sine nyvundne venner, Maria (i denne del af bogen benævnt "friherreinden") og hendes daværende mand, for at sejle til Frankrig. Efter at en kvindelig medpassager med sovemiddel og moderlig omsorg har lullet ham i søvn i køjen, vågner han til oprørte bølger og et landskab, der forekommer ham ubekendt. Han gribes af "dumpt raseri" og "fortvivlelse", men få linjer senere af "voksende ro" og "glæde" (Strindberg IO4), alt imens landskabet pludselig bliver ham dobbelt genkendeligt, dels fra barndommen, dels fra forårets udflugter med friherreinden og hendes mand. Det er et af de mange steder, hvor den retrospektive beretnings præteritum slår om i præsens: ”Og nu forekommer det mig at jeg ser hende på balkonen, viftende med silkelommetørklædet, råbende på mig med sin klare stemme...” (Strindberg I05) Den suggestionskraft, hvormed 
det erindrede billede melder sig i den fortalte tid, bryder igennem også til den fortællende tid, så billedet endnu en gang bliver præsent, må præsenteres i præsens. Jeget fortryder sin afrejse og bliver sat i land på en skærgårdskyst, hvor havets skiftende farver "fra hele skalaen af brunt over flaskegrønt, preussisk blåt til det snehvide bølgeskum" (Strindberg I08) akkompagnerer endnu en række heftige følelsesomslag (fortvivlelse, brændende begær, angst, dødslængsel). I den hensigt at pådrage sig dødelig lungebetændelse (!) springer jeget i det iskolde vand og føler sig "nedsænket i glødende lava”, hvorefter han sætter sig nøgen på en klippe: ”Den iskolde vind gennemborede lænden som et glødende jern.” (Strindberg IIo) Heftigheden kulminerer, i analogi til indledningens febersygdom, i en samtidighed af isnende kulde og glødende varme; simultaniteten af temperaturskalaens poler bliver det fysiske billede på simultaniteten af indbyrdes modsatte affekter.

\section{Paranoia}

Paranoiaen er en tilbagevendende tematiseret følelse i En dåres forsvarstale. Indledningens lange indre "undersøgelse" udmunder i en paranoid mistanke om, at hustruen skjuler en "forbrydelse": "en ubevidst lille forbrydelse fremkaldt af ubestemt magtlyst, af hunnens hemmelige begær efter at få overtaget over hannen i den tvekamp som kaldes ægteskabet!” (Strindberg 28) Axel mistænker jævnligt, at han er offer for en lesbisk sammensværgelse, og at han slet ikke er far til sine børn. I fuldt flor står paranoiaen, da han læser "et drama af den berømte norske blåstrømpeprofet" og heri tror at finde en detaljeret udlevering af sit eget ægteskab. Paranoiaen vinder her over al logik; Axels læsning hviler helt og aldeles på antagelsen af, at stykket handler om ham selv, og når noget ikke passer ind i denne forståelse, får det ham ikke til at revidere den, men blot til at registrere en obskuritet i teksten: "Hvad pigens illegitime herkomst angår, forstår jeg slet ikke analogien, for min datter så ikke dagens lys før vi havde været gift i to år.” (Strindberg 273) (Her endnu et eksempel på, at datidsberetningen slår om i præsens; det fortalte jegs grublerier er stadig det fortællende jegs.)

Men ét er den tydeligt tematiserede paranoia, noget andet om der findes noget paranoidt i selve tekstens udsigelse? Med en vis ret kan man kalde selve apologien for en paranoid genre, for så vidt som den ikke er svar på en reelt foreliggende anklage. I sit anslag (de to forord) svarer bogen på en imaginær anklage (at anklagen så i Tyskland efterfølgende skulle blive et juridisk faktum, er en anden sag). Der er også noget paranoidt over den jævnligt genkommende struktur af indre dialog, hvor jeget stiller sig selv spørgsmål i en slags paranoid konjunktiv: "Kunne det forholde sig sådan, at en forbrydelse skjulte sig?", "Kunne det forholde sig sådan, at jeg helt enkelt var blevet duperet?" (Strindberg 28).

Paranoia er en af de følelser, Sianne Ngai har med i sit katalog over "ugly feelings". For at komme ind under kategorien "ugly" skal en følelse ifølge Ngais definition udmærke sig ved at være ildeset, ikke-katarsisk, vedvarende og selvrefleksiv. Den paranoia, Ngai skildrer, har et diffust objekt. Det er følelsen af, at "systemet" 
hele tiden styrer dit liv, at du aldrig kan undslippe. Hun fremhæver, hvordan der er en forbindelse mellem paranoia og teori, fra enhver konspirationsteori til enhver systemkritisk teori. (Ngai 300) Men ligeledes at denne teoriproduktive paranoia konventionelt er knyttet til mandekønnet, mens kvindelig paranoia er blevet knyttet til jalousi. (Ngai 30I) Ngais pointe bliver bl.a., at vi har brug for paranoiaen, hvis ikke vi skal blive blinde for de ideologiske systemer (herunder patriarkatet), vi er underkastet. Den konsekvent paranoide vil mistænke selv at være del af det system, han eller hun føler sig forfulgt af. Denne mekanisme påpeger Ngai i sit litterære eksempel på en paranoid stemme fra den amerikanske avantgardelyrik, Juliana Spahrs Response (I995), som både kritiserer og indser sin egen medvirken i en bureaukratisk instrumentalisering af sproget.

Umiddelbart kan jegfortællerens paranoia hos Strindberg ikke siges at have et diffust objekt; det er med al tydelighed Kvinden, han føler sig forfulgt af. Men det diffuse bliver alligevel karakteristisk for følelsen; nogen (men hvem?) ved noget (men hvad?) som han ikke ved; hustruen dækker over en forbrydelse (men hvilken?); han er ikke far til sine børn (men hvem er det så?). Og udsigelsens omskiftelighed, de bestandige toneskift fra vrede til forelskelse til foragt til tvivl, relativerer ligeledes den sikre lokalisering af den forfølgende instans til Kvinden.

Men kan man tale om, at den paranoide her selv arbejder med på det, han føler sig forfulgt af? Og kan man tale om, at hans paranoia har et systemkritisk potentiale?

Strindbergs roman udviser ikke avantgardelyrikkens bevidsthed om selv at være en del af det, den kritiserer. Men alt imens fortælleren raser mod kvinden, kommer hans udsigelse til at antage nogle af de træk, han dadler kvinden for: hysterisk og lunefuld. (Noget Margaretha Fahlgren også har fat i, når hun kalder romanen for en mandlig, hysterisk tekst og bemærker Axels identifikation med den galskab, som han tilskriver Maria. Fahlgren 45, 50.) Hele den afsmitningslogik, som har sit tematiske udtryk i fortællerens (igen lettere paranoide) tro på kemiske valgslægtskaber (Strindberg 87) og ansigters aftryk i ansigter (Strindberg II7), præger også udsigelsen, der med sin hysteriske og omskiftelige tone kunne siges at være konventionelt "kvindelig". Hvis den "kvindelige" paranoia konventionelt er blevet knyttet til jalousi, så er Strindbergs fortæller kvindelig. Når fortælleren appellerer til et "jer", der skal overbevises om hans offerstatus, er det affektivt på kanten af, hvad en juridisk forsvarstale ville kunne rumme, og nærmer sig i stedet venindesnak.

Ligeledes kan man sige, at Strindbergs paranoia over for kvinden kommer til at gennempløje og dermed indeksere de kvindebilleder, der præger kulturen: madonna, hetære, hunpanter, kannibal, osv. At disse billeder veksler diffust hos fortælleren, samtidig med at han insisterer emfatisk på hver momentant gældende forestilling, giver os en fornemmelse af forestillinger, der er lige så kontingente, som de er bastante og virksomme. 


\section{Henvendelse}

Hvis vi nu, med Horace Engdahls stemmeanalytiske praksis som inspiration, vender os mod tekstens henvendelsesstruktur for at indfange dens stemme, må vi spørge: Til hvem henvender En dires forsvarstale sig, og hvordan?

"Undersøgelsen” i romanens indledning er præget af retoriske spørgsmål og (med udråbstegn markerede) udråb. Desuden overskrider henvendelsen indimellem den rene selvhenvendelse og retter sig mod "jer":

"Tænk jer dette: jeg beslutter mig for at forlade mit land, mine venner, min stilling, mine forlæggere for at tilfredsstille en nykke. Men hvad skal man gøre! Man elsker eller man elsker ikke.” (Strindberg 25)

Dette "jer" viser, at jeget ikke blot retfærdiggør sig over for sig selv, men også over for en eller anden offentlighed. Teknisk kan det også betragtes som en sammensmeltning af det fortællende og det fortalte jegs monolog; det fortalte jeg henvender sig strengt taget bare til sig selv i sygesengen, mens det fortællende jeg formidler hans indre forsvarstale til offentligheden. Som Rossholm viser, har det fortalte jeg i sygesengen og det fortællende jeg samme projekt: Undersøgelsen af Maria (Rossholm 220). Grænserne mellem fortællende og fortalt bliver utydelige, som det siden hen sker så ofte i romanens skift fra præteritum til dramatisk præsens, der forekommer affektivt motiveret: følelsen fra "dengang” er stadig præsent.

"Jer" kan i forsvarstalens modus forstås som nævningene, eller retssalens offentlighed, som taleren appellerer til. Men er der ikke også i Strindbergs "jer" en tone, der lyder mere af møde med veninderne på café? Sådan lidt "Kan I tænke jer, hvor slemt jeg er blevet behandlet, nu skal I bare høre her, hvor dum min kæreste har været mod mig."

I indledningen henvender jeget sig altså til et anonymt "jer", der glider mellem nævninge og venindeklub, og slutteligt til en læser, som samtidig er dommer: "Må den oplyste læser dømme upartisk i sidste instans ved at læse denne ærlige bog." (Strindberg 3I)

Dér hvor Rossholm finder, at tekstens henvendelser retter sig "til hele verden, dvs. til ingen" og derfor må betegnes som "deklamatoriske pseudo-adresseringer" (Rossholm 2I7), finder jeg snarere, at de understøtter tekstens paranoide tone, både i dens hysteriske ("venindeklub") og pseudojuridiske (nævninge, dommer) variant.

En direkte læserhenvendelse finder vi også senere i romanen, efter den kostelige historie om hustruens ækle King Charles-spaniel, der fodres med de lækre kalvekoteletter, som ægtemanden burde have haft, og forvandler fruens soveværelse fra "kærlighedsrede" til "hundehus". Her henvender fortælleren sig til en tænkt læser:

"Unge mand, du som læser denne sandfærdige bekendelse, du som har lidt mens du på to minutter læste denne historie om en hund, skænk mig da din dybeste 
medlidenhed, i og med at du multiplicerer seks med tre hundrede femogtres døgn a firetyve timer, og hav beundring for mig, som endnu er i live!" (Strindberg 2I8)

Med den "unge mand" som tænkt læser bliver tekstens stemme nærmest belærende: Læs og lær. Men samtidig er det ikke helt det, der står: Læs og hav medlidenhed. Læseren skal lide med det lidende jeg, men det lader sig kun gøre, hvis han multiplicerer den lidelse, teksten tænkes at vække i ham, med $6 \times 365 \times 24$. At disse tal bogstaveres i deres fulde udstrækning er medvirkende til at give bønfaldelsen et ekstra inderligt eftertryk. Den lidende stemme anråber den med-lidende læser, men diskrepansen mellem den retoriske patos og historiens emne ("min hustrus spaniel") har naturligvis en komisk effekt.

Den mest gribende henvendelse finder vi i bogens slutning. De sidste sider skildrer, hvordan jeget, fast besluttet på skilsmisse, drager af sted mod Frankrig for at påbegynde den roman, vi læser, men på rejsen kastes mellem modstridende følelser: sorgen ved afskedsbilledet af hustruens "fortryllende gestalt" på kajen, længslen efter familielivet, den strindbergske mands klassiske følelse af at være "et foster som er blevet skilt for tidligt fra navlestrengen” (Strindberg 303).

Konsekvensen af følelsesstriden bliver, at han kalder sin hustru ned til Bodensøen, hvor hun igen vækker et flimmer af skiftende affekter i ham, knyttet til de forskellige visioner, han har af hende: Den ældede kvinde med slæbende gang og rødgrædte øjne vækker hans medlidenhed; den poserende "tragédienne", der for fortælleren at se har taget gestalt efter sin lesbiske, danske veninde, vækker hans hån (Strindberg 305).

Den eneste måde bogen kan slutte på, er tilsyneladende ved et abrupt cut; den sidste oplysning vi får om jegets ægteskabshistorie, er, at han, efter fast beslutning om skilsmisse, "vender tilbage for sjette gang", ganske vist med den intention at afslutte sin "beretning” og "afvente nøjagtige undersøgelser vedrørende denne mystiske affære". (Strindberg 307) (Om "denne mystiske affære" henviser til ægteskabet i sin helhed eller noget mere specifikt, er ubestemt, hvilket understøtter bogens paranoide tone). Vi skrives altså ikke frem til ægteskabets slutpunkt, men til en situation af bestandig tilbagevenden.

Derefter springer romanen abrupt til sin sluterklæring:

"Nu er historien slut, min Elskede. Jeg har hævnet mig; vi er kvit .....

Denne kombinerede kærligheds- og hævnerklæring har altid virket voldsomt stærk på denne læser. Der ligger noget voldsomt alene i den abrupte måde, den melder sig på. Og i den pludselige, direkte henvendelse til hustruen; hendes forvandling fra tredje til anden person. Det kan give følelsen af, at teksten i en vis dimension hele tiden har været henvendt ikke til nævningene, ikke til dommeren, ikke til lidelsesfællerne, men til hende. Her klinger kærligheden og aggressionen, som teksten 
har pendlet frem og tilbage mellem, i én og samme kraftige slutakkord. Derpå de to lange rækker af tankeprikker, der står og bipper som tonen på et kardiogram, når alle udslag er ophørt ... Måske er denne latente henvendthed til hustruen noget af det, der giver romanens vrede stemme et forløsende potentiale. Dens vrede mod kvinden er også en kærlighed til kvinden, hvis vi tillader os en forståelse af kærligheden som en engageret rettethed, der ikke bare er mild og øm, men også aggressiv og voldsom.

Jeg gik til Strindberg med en vis forventning om at finde misogyn monomani og at kunne redde de æstetiske og etiske potentialer ud af den tone, der énstemmigt fremturer i sit urimelige ærinde. Men det, man mødes af, er snarere en omskiftelighed i tone og affekt, der følges med kalejdoskopet af hustrubilleder og finder sin allegori i skærgårdshavets skiftende lys og feberens skiftende ekstremtemperaturer.

Hvis vi vender tilbage til distinktionen mellem stemme og tone, kan vi så sige, at stemmen i En dares forsvarstale er skiftevis rasende, tilbedende, øm, paranoid, forelsket osv. - og at tonen er selve omskifteligheden? I analogien til forholdet mellem voice-over og underlægningsmusik, kunne jeg til Strindbergs uafbrudt kværnende fortællerstemme forestille mig en konsekvent kontrapunktisk underlægningsmusik. Således at der blev spillet med blide violiner under de rasende passager, og aggressivt slagtøj under de ømme, forelskede.

Selvom Strindberg vitterligt ofte kan lyde som en bitterfisse, der ville kunne rangeres under Nietzsches slavemoralske ressentiment, er der i selve hans maniske fremturen en kraft, der tydeliggør og ryster grundpladerne i det affektive kønssystem, som stadig er vores. Strindberg bladrer gennem det billedforråd, der under fallokratiet står til rådighed for opfattelsen af kvinden (madonna, heks, hysteriker, rovkat osv.) og af forholdet mellem kønnene (enten magtkamp eller mor/søn) og tydeliggør dermed disse billeder for os, hvad der kan være starten på at smadre dem. Romanens afsluttende akkord rummer den på én gang kærlige og aggressive henvendelse til det andet køn, som kunne være alternativet til et kønsforhold, der enten er sentimentalt idylliserende eller kamp til døden.

\section{LITTERATURLISTE}

Cohn, Dorrit. Transparent Minds: Narrative Modes for Presenting Consciousness in Fiction. Princeton, N.J.: Princeton University Press, 1978.

Engdahl, Horace. Beröringens ABC. En essä om rösten i litteraturen. Stockholm: Albert Bonniers förlag, 2005 [I994].

Fahlgren, Margareta. Kvinnans ekvation: Kön, makt och rationalitet i Strindbergs författarskap. Stockholm: Carlssons, I994.

Ngai, Sianne. Ugly Feelings. Cambridge, Massachusetts: Harvard University Press, 2005.

Rösing, Lilian Munk. ”När är en gatsten gudomligt våld? Om vredens politik och vredens litterära röster. Tidskrift för litteraturvetenskap 3-4, 2008, 45-60. 
Rösing, Lilian Munk. "Stemme”. Litteratur: Introduktion til teori og analyse. Red. Kjældgaard, L. H., Møller, L., Ringgaard, D., Rösing, L. M., Simonsen, P. \& Thomsen, M. R. Aarhus: Aarhus Universitetsforlag, 20I2, 7I-82.

Strindberg, August. En dåres försvarstal. Oversat fra fransk af Hans Levander. Stockholm: Norstedts, 2012.

Stenport, Anna Westerståhl. Making Space: Stockholm, Paris and the Urban Prose of Strindberg and His Contemporaries. Berkeley: University of California, 2004. 